\section{Against instant books}

Stephen H. Schneider of the National Center for Atmospheric Research, Boulder, Colorado, explains why he feels that 'instant' books often do more to confuse than elucidate the scientific controversies they discuss.

TIME and again in recent years a chorus of social pundits has bemoaned the increasingly hectic pace of modern living. Among the shopping list of adverse side effects frequently cited are the break up of the cohesiveness of the family unit, the rise in feelings of societal alienation of many young people, the increase of environmental pollution, the rise of junk foods, and the alarming rate of stress-related disease. To this growing list we must add a contribution from the publishing industry: the 'instant book'.

For example, very soon after the harsh "Winter of 1977" in the United States, as it is often called, we have The Weather Conspiracy: The Coming of the New Ice Age (Ballantine, New York, 1977). It has many of the trappings of an instant book. Since its 'author' is "The Impact Team", a group of 18 non-weather experts calling themselves reporters, writers, researchers, and "back-up" (whatever that means) people, they had to turn elsewhere for scientific credibility. They chose the wrong people.

Space doesn't permit a detailed critique of the two CIA reports on climate, which are the basis for The Weather Conspiracy and are included as appendices, and upon which the book leans so heavily for what it calls "true facts". I must, however, mention that Professor Reid Bryson of the University of Wisconsin, whom the CIA and the Impact Team cite as the expert predicting most of the coming climatic disasters, has publicly repudiated much of the CIA reports: and they quote him as a principal source of specific climatic predictions. Bryson objected for the simple rcason that the predictions were specific-something which is beyond the state-of-the-art skills of climatologists. In fact, much of the CIA reports depend on the pre-1974 views of Bryson, and he has himself argued that new evidence has required him, as any good scientist, to revise and recast his views. In essence, I would characterise parts of the CIA reports that predict the climatic future as "Early Bryson extrapolated", and much of The Weather Conspiracy thus as "Early CIA extrapolated".

I must, however, confess nagging conflicts that bother $\mathrm{mc}$ in using The Weather Conspiracy as a butt:

- it includes an impressive amount of material on climate, even if there is little cohesive thinking to link it together; and I don't want to take the purist role and discourage all mass market attempts to "spread the word" about the very real dangers climatic issues do pose for society merely because such polarisations simplify complex issues;

- many of the Impact Team's proposed solutions to these dangers, that is, food reserves, weather control treaties, energy conservation, and so on, while not new to those who follow the issues, are plausible and need widespread exposure-something a mass market book can do well;

- most importantly, as one whose own book, The Genesis Strategy: Climate and Global Survival (Plenum, 1976 and Delta, 1977), is itself an attempt to raise public consciousness about many of the issues repeated in The Weather Conspiracy, I am keenly aware of possible scepticism some might express about one author's seemingly pejorative treatment of a subsequent competitive book. The best that I can do to dispel any such possible suspicion is to state clearly why I believe a "pot boiler" like The Weather Conspiracy could really retard the efforts of those who seek to persuade society to anticipate and then hedge against the possibility of future climate-induced catastrophe--a goal that seems common to me and the Impact Team.
Commendably, The Weather Conspiracy does bore deeply into many of the issues of future climatic warmings and coolings, but instead of pointing out that either scenario for climatic change could be troublesome since much of human activity, particularly agricultural, is tuned to the present climate, it insists on maintaining the shock effect of the dramatic (the subtitle reads, "The Coming of the New Ice Age") rather than the reality of the discipline; we just don't know enough to chose definitely at this stage whether we are in for warming or cooling-or when. Nor, is The Weather Conspiracy alone in choosing sides in a scicntific debate which is just not resolvable with present knowledge. Two other recent popular books by nonmeteorologists give away their opposing advocacies in their titles: Hot House Earth versus The Cooling.

The damage to the authors' common cause of action on public policy from all three books is that they have been discredited publicly by many in the scientific community as sensationalist and technically inaccurate. Thus, in the confusing banter among experts-some pushing cooling, some pushing warming--the public and their elected officials usually shrug and say, "I,et the scientists study more until they are sure what will happen".

That is precisely one of the greatest inadequacies that governmental institutions exhibit with regard to scientific controversies. They of ten confuse debates among scientists as a justification for a 'wait and see' attitude on policy considerations. Unfortunately, many controversial, unresolved scientific components of public policy issues, for example, the danger of nuclear power plants, the banning of saccharin or the landing rights of Concorde in New York, are not resolvable before decisions have to be made.

What policy makers need, therefore, is a realistic assessment of what is and isn't known about the science of problems like climatic change, along with some estimates of the vulnerability of different segments of society to a variety of plausible climatic scenarios; and also, some estimate of how long it might take the scientific community to reduce the large uncertainty that exists over the alternative projections of the future.

One hopes we do not need overstated scientific certainty to scare the system into action, for no doubt as soon as one group overstates the strength of scientific evidence to advocate a policy change, someone else advocating an opposing policy will be quick to point out the omissions or errors in the technical evidence, and will challenge the credibility of the original advocate's views-especially their policy options. The result is usually a delay in action, not a speed-up, for the added confusion slows up the process.

If accurate information is a key for society to survive the increasing complexity of the technological props that support its cxistence, then we must also learn to deal with the bewildering uncertainties surrounding the safety and acceptability of these props, and be willing to make value judgements as to whether we should hedge against the most plausible catastrophes that present knowledge can estimate. If this kind of common sense planning for insurance against plausible nasty surprises in the future can only follow from overstated cases shrieked out of instant books or from television news programmes; if we are unwilling to put in the time to follow in some detail just what science does and does not know about the range of potential technological crises, we will fall into crisis after crisis, under-reacting in advance and over-reacting afterwards.

As I have chosen The Weather Conspiracy as a point of departure to argue how books should not treat scientific controversies, let me return to it. Instead of meeting its page one stated purpose: "to inform the public of the true facts about a topic often clouded by fiction, superstition, and alarmist misrepresentation", The Weather Conspiracy leads the pack in clouding up further precisely what it is intended to clear. 